\title{
Economic Impact of Modern Technology on Plantain Production ${ }^{1}$
}

\author{
Edgardo González Villafañe ${ }^{2}$ \\ ABSTRACT
}

As a result of applying modern technology recommended by the Agricultural Experiment Station, modern plantain (Musa sp.) farmers (innovators) obtained an average yield of 86,009 fruits/ha, produced 5,441 setts $/$ ha, and had a net profit of $\$ 5,241.29 / \mathrm{ha}$, while traditional farmers produced 58,166 fruits/ha, 1,765 setts/ha and obtained a net profit of $\$ 2,146.99 / \mathrm{ha}$.

\section{INTRODUCTION}

Plantain is the most important starchy crop in Puerto Rico; it ranks third in importance among all food crops. Plantain production amounted to 318 million fruits in $1979-80 .^{3}$ Gross income from this commodity amounted to $\$ 31.7$ million, equivalent to $15 \%$ of the farm value of all crops ( $\$ 211.1$ million), and $6 \%$ of the Island's total gross agricultural income ( $\$ 578.7$ million). Although an increase of 21 million fruits was registered in the 1979-80 crop, total production was not enough to match local consumption, thus it was necessary to import 1,207 metric tons of plantains.

During the last decade, two studies of the economic situation of commercial plantain growers were conducted by the Agricultural Experiment Station. ${ }^{4,5}$ Results indicated that throughout the years production costs per hectare have increased consistently and labor productivity has diminished; moreover, climatic variations, labor scarcity, pest and disease control are problems that continue to trouble plaintain farmers. The studies showed that price increases along with increased government incentives have been enough to offset increases in production costs thus leaving farmers in a fairly good economic position. Results also indicated that throughout the years farmers have adopted a limited amount of the modern technology developed and recommended by the Agricultural Experiment station.

This study was conducted to determine the effect that the modern

\footnotetext{
' Manuscript submitted to Editoral Board June 12, 1981.

${ }^{2}$ Economist, Agricultural Experiment Station, Mayagüez Campus, University of Puerto Aico, Rio Piedras, P.R.

${ }^{3}$ Departamento de Agricultura, 1981, Ingreso Agrícola de Puerto Rico, 1978/79$1979 / 80$.

${ }^{4}$ Espinet-Colón, G., González-Villafañe, E., Muler-Manzanares, L. and Chavarría de Gracia, O., 1973, Análisis Económico de la Producción y Mercadeo del Plátano a Nivel del Productor, Puerto Rico, 1971-72, Pub. 82, Agr. Exp. Sta., Univ. P.R.

${ }^{5}$ González-Villafañe E., Espinet, G. R. and Troche-Ducot, J. L., 1978. Análisis Económlco de la Producción de Plátanos en Puerto Pico, Pub. 124, Esta. Exp. Agric., Univ. P.R.
} 
cultural practices have had on plantain production and to compare the profits of innovators versus those of traditional plantain growers.

\section{MATERIALS AND METHODS}

Two groups of plantain growers were used for this study. One group included 28 farmers who, according to Agricultural Extension Agents, utilized more intensively all or most of the modern cultural practices recommended by the Agricultural Experiment station. Farmers were selected and interviewed in 1980 for information about their farm operation in fiscal year 1979-80. The other group consisted of 118 plantain farmers who followed traditional cultural practices generally applied in the east-central Agricultural Region of Puerto Rico. This group of farmers was interviewed in 1978 for farm management information for fiscal year 1976-77.

Multiple regression analyses were conducted to determine the variation in yield and production of setts per hectare that was accounted for by selected independent variables: age of farmer, education of farmer, area in plantains, farm size, farm ownership, topography of the area devoted to plantains, and the utilization of cultural practices such as proper land preparation, fertilization, chemical weed control, insect and disease control, use of recommended varieties and planting distances. In addition, an analysis of cost production determined to what extent the use of modern technology increased farmers' income.

\section{RESULTS AND DISCUSSIONS}

Results indicated that the independent variables included in the analysis explained $81 \%\left(r^{2}=0.811^{* *}\right)$ of the variation in yield of plantains per hectare and $70 \%\left(r^{2}=0.698^{* *}\right)$ of the variation in the number of setts produced per hectare. All variables, except education of the farmer and topography of the area devoted to plantains, were significantly correlated with the yield of plantains per hectare, and all except farm size were significantly correlated with the number of setts produced per hectare.

There were marked differences between farmers using modern technology and those utilizing conventional practices. The following tabulation summarizes some of the outstanding differences:

\begin{tabular}{lccc}
\multicolumn{1}{c}{ Variable } & Unit & Innovators & $\begin{array}{c}\text { Traditional } \\
\text { farmers }\end{array}$ \\
Age & Years & 48.8 & 54.8 \\
Instruction & Years & 8.5 & 5.7 \\
Area in plantains & & & \\
$\quad$ Under study & $\mathrm{Ha}$ & 2.3 & 1.6 \\
$\quad$ Other & $\mathrm{Ha}$ & 9.4 & 1.7 \\
Area in other crops & $\mathrm{Ha}$ & 1.3 & 3.9 \\
Area in non-crop uses & $\mathrm{Ha}$ & 15.3 & 10.1 \\
Total farm area & $\mathrm{Ha}$ & 28.3 & 17.3
\end{tabular}


While all innovators planted recommended plantain varieties, only two-thirds of the traditional farmers did so. Furthermore, innovators used 477 more setts/ha $(2,477$ vs. 2,000$)$ and 1.1 metric ton/ha more fertilizer than traditional farmers ( 3.6 vs. 2.5 ).

It was found that innovators followed the recommended practices more closely than traditional farmers. The following tabulation shows that although innovators are not using $100 \%$ of the modern practices, they follow more of them than the traditional farmers.

\begin{tabular}{|c|c|c|}
\hline Cultural practice & Innovators & $\begin{array}{l}\text { Traditional } \\
\text { farmers }\end{array}$ \\
\hline & \multicolumn{2}{|c|}{ Percentage of users } \\
\hline Plowing & 92.9 & 73.7 \\
\hline Raking & 35.7 & 1.7 \\
\hline Ditching & 89.3 & 78.8 \\
\hline Insect and nematode control & 78.6 & 36.4 \\
\hline \multicolumn{3}{|l|}{ Weeding } \\
\hline By hand alone & 25.0 & 82.0 \\
\hline By hand and herbicide & 57.0 & 16.0 \\
\hline By herbicide alone & 18.0 & 2.0 \\
\hline Disease control & 85.7 & 33.0 \\
\hline
\end{tabular}

Another outcome of utilizing the recommendations of the Agricultural Experiment Station more fully was that innovators produced $47.9 \%$ more fruits/ha $(86,009$ vs. 58,166$)$ and $208 \%$ more setts/ha $(5,441$ vs. 1,765$)$ than traditional farmers.

Cost-and-return analysis showed that innovators had an average cost of production amounting to $\$ 5,268.52 /$ ha. Average gross income was $\$ 10,509.81$; their net profit was $\$ 5,241.29 / \mathrm{ha}^{6}{ }^{6}$ Traditional farmers had an average total costs of $\$ 3,874.59$, a gross income of $\$ 6,021.58$ and a net profit of $\$ 2,146.99 / \mathrm{ha}^{\text {, }}$

It was also observed that innovators increased labor productivity dramatically by adopting the recommended technology. While traditional farmers required 2.85 man-days to produce a thousand fruits, innovators required only 1.26 man-days/thousand fruits. Increased production per hectare, more intensive use of machinery in land preparation, and the use of herbicides to replace hand weeding were factors basically responsible for this increase in labor productivity.

Results clearly demonstrate that innovators obtained increased yields, sett production, labor productivity, and net earnings. A main priority should be the adoption of these modern cultural practices by traditional as well as new farmers. A combined effort by the Commonwealth De-

\footnotetext{
${ }^{6}$ Gonzâlez-Villafañe, E., Análisis Económico de Fincas Commerciales de Plátanos en las que se Utilizan Prácticas Agricolas Modernas, (Submitted for publication), Esta. Exp. Agric., Univ. P.R.
} 
partment of Agriculture and the Agricultural Extension Service is of utmost importance.

\section{RESUMEN}

Una comparación se llevó a cabo entre 28 productores de plátanos innovadores y 118 agriculores que seguían el sistema tradicional de siembra. Se encontraron marcadas diferencias entre ambos grupos. Los innovadores eran más jóvenes, tenían más instrucción escolar, fincas más grandes, siembras de plátanos más extensas, y ademàs, no solamente un porcentaje mayor usaba las prácticas modernas, sino que las utilizaban mejor. Como resultado, los innovadores lograron una producción de 86,009 plátanos/ha, 5,441 semillas (retoños)/ha y una ganancia neta de $\$ 5,241.29 / \mathrm{ha}$, mientras que los agricultores tradicionales obtuvieron un rendimiento medio de 58,166 plátanos/ha, 1,765 semillas/ ha y una ganancia neta de $\$ 2,146.99 /$ ha. Además, los innovadores registraron una marcada mejoría en la productividad obrera. 